\title{
Linfoma angioimunoblástico de células T
}

\author{
Angioimmunoblastic T cell lymphoma
}

Os linfomas de células T periféricos (LCTP) constituem um grupo heterogéneo de neoplasias correspondente a menos de 15\% de todos os linfomas não Hodgkin (NH). ${ }^{1} 0$ linfoma angioimunoblástico de células T (LAIT) é um subtipo de LCTP com caraterísticas clínicas, patológicas e imunofenotípicas particulares, cujo diagnóstico pode ser desafiador e que acarreta um mau prognóstico. ${ }^{2-4}$

Apresenta-se o caso de um homem, 93 anos, sem antecedentes patológicos de relevo, internado por febre e anorexia com um mês de evolução sem alívio com antipiréticos ou antibioterapia empírica. Negava outra sintomatologia. Ao exame físico apresentava-se febril, hemodinamicamente estável, eupneico, sem sinais de dificuldade respiratória. Objetivada palidez, desidratação, adenopatias periféricas generalizadas e erupção cutânea no tórax. Auscultação sem alterações, abdómen indolor, com esplenomegalia e sem massas palpáveis. Analiticamente destacava-se pancitopenia (hemoglobina 9.9 g/dL, plaquetas 10500/uL, linfócitos 550/uL), elevação da lactato desidrogenase lática (729 U/L), da velocidade de sedimentação (71 $\mathrm{mm} / \mathrm{h})$ e da proteína C reativa $(10,97 \mathrm{mg} / \mathrm{dL})$, hipoalbuminemia, eletroforese proteínas séricas normal. Cumpriu antibioterapia empírica de largo espetro suspensa após resultados negativos do rastreio sético. A biópsia de gânglio linfático axilar revelou: supressão completa da sua arquitetura por processo linfoproliferativo NH com extensão focal aos tecidos extracapsulares ganglionares (Figura 1); estudo imunohistoquímico com marcação da população linfóide para CD3, CD5, CD10 e Ki67, marcação de raras células linfóides para CD20 e CD79a e marcação de rede peri-vascular de células foliculares dendríticas para CD21: achados compatíveis com LAIT (Figura 2). ${ }^{3-5}$ Iniciou 40 mg de prednisolona por dia com melhoria clínica e analítica sendo orientado para Hematologia. Contudo o doente recusou ser submetido a qualquer procedimento invasivo, decidindo-se manter a corticoterapia. 0 doente faleceu meses depois.

Este caso alerta para uma patologia agressiva e pouco frequente e para a necessidade constante de respeitar a decisão de cada doente, assegurando que este esteja devidamente informado das consequências dos seus atos.

The peripheral T cell lymphomas (PTCL) are a heterogeneous group of neoplasms corresponding to less than $15 \%$ of all non-Hodgkin (NH) lymphomas. ${ }^{1}$ Angioimmunoblastic T cell lymphoma (AITL) is a PTCL subtype with particular clinical, pathological and immunophenotypical features, whose diagnosis can be challenging and that carries a poor prognosis. ${ }^{2-4}$

We report a case of a 93-years-old man, without relevant past medical history, admitted with fever and anorexia with a month of evolution without relief with antipyretics or empirical antibiotics. He denied other symptoms. At physical examination he was feverish, hemodynamically stable, eupneic, without respiratory distress signals. Objectified pallor, dehydration, generalized peripheral lymphadenopathy and rash on the chest. The auscultation hadn't alterations and the abdomen was painless, with splenomegaly and no palpable masses. Analytically we highlight: pancytopenia (hemoglobin $9.9 \mathrm{~g} /$ dL, platelets 10500/uL, 550 lymphocytes/uL); elevated lactate dehydrogenase lactate $(729 \mathrm{U} / \mathrm{L})$, sedimentation rate $(71 \mathrm{~mm} / \mathrm{h})$ and C-reactive protein $(10,97 \mathrm{mg} / \mathrm{dL})$; hypoalbuminemia and a normal serum protein electrophoresis. He was under broad spectrum empirical antibiotic that were suspended after negative results of septic screening. The biopsy of axillary lymph node revealed: complete
Figura 1. Imagem histológica de biópsia do gânglio linfático HE 10x: desarranjo arquitetural por processo linfoproliferativo com extensão focal aos tecidos extracapsulares ganglionares de composição celular polimorfa, acompanhada de rede vascular capilar arvorescente e predomínio de pequenas células linfóides de citoplasma clarificado com diversas células linfóides de aspeto ativado disperso.

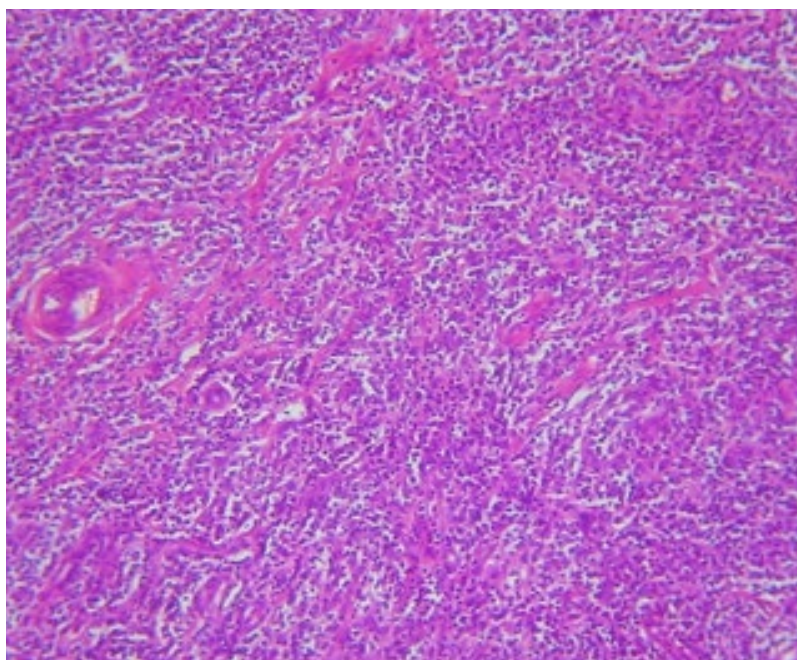

Figura 2. Marcação imunohistoquímica compatível com linfoma angioimunoblástico de células T: A-marcação para CD3, B-marcação para CD5,C-marcação para CD10,D-marcação para CD21

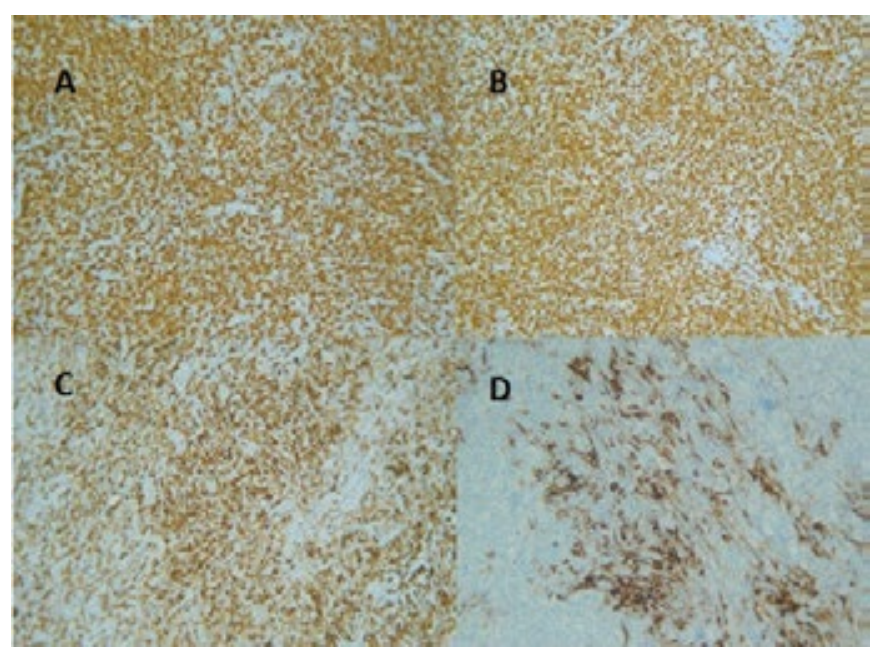

effacement of its architecture by NH lymphoproliferative process with focal extension to extracapsular lymphatic tissue (Figure 1); immunohistochemistry study with lymphoid population staining for $\mathrm{CD} 3, \mathrm{CD} 5, \mathrm{CD} 10$ and Ki67, rare lymphoid cells staining for CD20 and CD79a, and CD21 staining for peri-vascular network of follicular dendritic cells: findings consistent with AITL (Figure 2)..$^{3-5} \mathrm{He}$ started $40 \mathrm{mg}$ of prednisolone daily with clinical and analytical improvement with orientation to Hematology. However the patient refused to undergo any invasive procedure, deciding to keep steroids. The patient died months later. This case alert for an uncommon aggressive disease and the constant need to respect the decision of each patient, ensuring that he is properly informed of the consequences of their actions. 


\section{Bibliografia}

1 Rizvi MA, Evens AM, Tallman MS, Nelson BP, Rosen ST. T-cell non-Hodgkin lymphoma. Blood 2006;107:1255-1264.

2 Pircher A, Verdorfer I, Brunner A, Hopfinger G, Steurer M. Paraneoplastic Phenomena and Diagnostic Challenges in Angioimmunoblastic T-Cell Lymphoma (AITL): Report of Two Cases and Review of the Literature. In Vivo 2014;28(3):327-332.

3 Feller AC, Griesser H, Schilling CV, Wacker HH, Dallenbach F, Bartels H, et al. Clonal gene rearrangement patterns correlate with immunophenotype and clinical parameters in patients with angioimmunoblastic lymphadenopathy. Am J Pathol 1988; 133:549-556.

4 Mourad N, Mounier N, Brière J, Raffoux E, Delmer A, Feller A, et al. Clinical, biologic, and pathologic features in 157 patients with angioimmunoblastic T-cell lymphoma treated within the Groupe d'Etude des Lymphomes de l'Adulte (GELA) trials. Blood 2008:111:4463-4470.

5 Attygalle A, Al-Jehani R, Diss TC, Munson P, Liu H, Du MQ, et al. Neoplastic T cells in angioimmunoblastic T-cell lymphoma express CD10. Blood 2002;99:627-633.

\section{Diagnóstico:}

\section{Linfoma angioimunoblástico de células T}

Cátia Pereira ${ }^{1}$, Nuno Tavares ${ }^{2}$

${ }^{1}$ Interna complementar de Medicina Interna, Serviço de Medicina Interna, Unidade Local de Saúde do Nordeste - Unidade Hospitalar de Bragança

${ }^{2}$ Interno complementar de Oncologia Médica, Centro Hospitalar de São João

Serviço de Medicina Interna da Unidade Local de Saúde do Nordeste - Unidade Hospitalar de Bragança

Correspondencia: cmlpmed@gmail.com

Como citar este artículo: Pereia C, Tavares N

Linfoma angioimunoblástico de células T. Galicia Clin 2015; 76 (4): 182-183

Recibido: 07/07/2015; Aceptado: 04/09/2015 